\title{
PENGARUH BAURAN PEMASARAN TERHADAP KEPUTUSAN PEMBELIAN ULANG SEPEDA MOTOR HONDA DI PT. MENARA AGUNG VETERAN
}

\author{
Gusri Nofina, Febsri Susanti \\ Sekolah Tinggi Ilmu Ekonomi "KBP” \\ febsrisusanti@akbpstie.ac.id \\ gusrina27nofina@gmail.com
}

\begin{abstract}
ABSTRAK
Penelitian ini dilakukan dengan tujuan untuk mengetahui pengaruh bauran pemasaran terhadap keputusan pembelian ulang sepeda motor honda di PT.Menara Agung Veteran Padang. Instrumen yang digunakan dalam penelitian ini berupa kuesioner yang terdiri atas sejumlah pernyataan mengenai produk, harga, promosi, tempat dan keputusan pembelian ulang. Penelitian ini menggunakan sampel jenuh, dimana seluruh populasi penelitian akan dipilih menjadi sampel penelitian yaitu sebanyak 100 orang. Teknik analisis data yang digunakan dalam penelitian ini adalah regresi linear berganda digunakan untuk mengetahui pengaruh bauran pemasaran(Produk, Harga, Promosi, Tempat) terhadap keputusan pembelian ulang. Hasil penelitian didapat variabel bebas yang berpengaruh signifikan terhadap keputusan pembelian adalah variabel produk dan tempat. Sedangkan variabel harga dan promosi tidak berpengaruh signifikan terhadap keputusan pembelian.
\end{abstract}

Kata kunci : Produk, Harga, Promosi, Tempat, Keputusan pembelian

\section{PENDAHULUAN}

Dewasa ini perkembangan dunia usaha terutama dunia teknologi di Indonesia berkembang dengan pesat. Perkembangan dunia teknologi khususnya sepeda motor merupakan suatu jawaban dari tuntutan kebutuhan masyarakat terhadap tingkat dan kualitas hidup yang semakin meningkat pula. Bagi masyarakat saat ini sepeda motor sangat menunjang mobilitasnya dalam melakukan aktifitas. Bisa dikatakan sebagian besar masyarakat Indonesia kususnya dikota Padang baik dari kalangan muda sampai tua memiliki dan membutuhkan sepeda motor.

Dengan semakin banyaknya permintaan sepeda motor saat ini maka secara otomatis muncul banyak perusahaan sepeda motor yang sejenis. Hal ini menyebabkan terjadinya persaingan yang ketat, setiap produsen dituntut untuk mempunyai keunggulan tersendiri agar mampu bersaing. Dalam hal ini peranan hal bauran pemasaran sangat penting karena kegiatan tersebut memberikan pengaruh terhadap kelangsungan hidupan perusahaan kususnya dalam memperoleh laba. Menurut swasta (2002 : 24) marketing mix adalah kombinasi 
dari empat variabel atau kegiatan yang merupakan inti dari sistem pemasaran perusahaan, yakni produk, struktur harga, kegiatan promosi, dan tempat.

Defenisi produk secara luas menurut tjibtono (2008 : 95) adalah pemahaman subyektif dari produsen atau suatu yang bisa ditawarkan sebagai usaha untuk mencapai tujuan organisasi melalui pemenuhan kebutuhan dan keinginan konsumen, sesuai dengan kompetensi dan kapasitas organisasi serta daya saing beli pasar. Pasar sangat menyukai produk yang mempunyai kualitas yang terjamin. Kualitas yang bagus dengan sendirinya akan menciptakan harga yang tinggi juga. Harga merupakan satuan moneter atau ukuran lainnya (termasuk barang dan jasa lainnya) yang ditukarkan agar memperoleh hak kepemilikan atau penggunaan suatau barang atau jasa (Tjibtono, 2008 : 152).

Perusahaan harus mengenalkan produk yang dimilikinya kepasar dengan cara melakukan berbagai promosi. Promosi adalah arus informasi atau persuasi satu arah yang dibuat untuk mengarahkan seseorang atau organisasi kepada tindakan yang meciptakan pertukaran dalam pemasaran (Swasta dan Sukotjo, 2002 : 222). Promosi dapat dilakukan dengan berbagai media yang ada mulai dari cetak sampai elektronik.

Bauran pemasaran yang efektif menjadi basis strategi perusahaan dalam melaksanakan program pemasaran yang dikendalikan dan digunakan perusahaan untuk mencapai target penjualan dalam pasar sasarannya. Strategi pemasaran menurut Lamb, Hair dan McDaniel (2001 : 54) adalah suatu kegiatan menyeleksi dan penjelasan satu atau beberapa target pasar dan mengembangkan serta memelihara bauran pemasaran yang akan menghasilkan keputusan bersama pasar yang dituju. Ada banyak produsen sepeda motor terkemuka di Indonesia, salah satunya adalah Honda. Honda telah mendapatkan tempat yang istimewa dihati konsumen Indonesia. Konsumen banyak yang menjatuhkan pilihan mereka ke Honda dengan banyak pertimbangan. Walaupun sudah mendapatkan tempat dihati konsumen sepeda motor di Indonesia. Honda menyadari adanya persaingan dengan perusahaan sejenis. Oleh karena itu untuk tetap mempertahankan posisi dan memenangkan persaingan, Honda menyusun suatu strategi pemasaran untuk menciptakan, mempengaruhi, mendorong atau meningkatkan sikap positif yang dapat menguntungkan perusahaan sekaligus berusaha meningkatkan kepuasan pelanggan. Kesulitan yang sering dialami oleh perusahaan dalam menerapkan strategi pemasaran adalah informasi yang kurang akurat tentang konsumen.

Untuk mendapatkan informasi yang akurat tentang hal konsumen pertama yang harus dilakukan perusahaan adalah mengetahui perilaku konsumen. Perilaku konsumen menurut Lamb, Hair dan McDaniel (2001 : 188) merupakan suatu proses pelanggan dalam membuat keputusan membeli, juga untuk menggunakan dan membuang barang-barang dan jasa yang dibeli, dan juga termasuk faktorfaktor yang mempengaruhi keputusan pemelian dan penggunaan produk. Dengan mengetahui perilaku yang ditunjukan oleh konsumen maka akan membantu produsen untuk menciptakan suatu produk yang sesuai dengan yang di inginkan konsumen tersebut.

Dalam menetapkan strategi pemasarannya Honda menentukan beberapa kebijakan, kususnya pada bauran pemasaran. Bauran pemasaran dapat memberi daya tarik kepada konsumen. Faktor-faktor bauran pemasaran akan 
mempengaruhi keputusan konsumen dalam melakukan pemelian sepeda motor Honda. Setiap konsumen bauran pemasaran dapat memberikan pengaruh positif atau negatif terhadap keputusan pembelian konsumen. Jika bauran pemasaran memberikan pengaruh positif maka akan memperkuat keputusan pembelian atau konsumen akan melakukan pembelian ulang untuk suatu produk yang sama dan jika memberikan pengaruh negatif maka akan memberikan semakin melemahnya keputusan pembelian atau konsumen tidak akan lagi membeli produk yang sama.

Permintaan akan sepeda motor terus mengalami peningkatan dari tahun ke tahun. Masyarakat kota Padang banyak menggunakan sepeda motor sebagai alat penunjang mobilitasnya karena dinilai sangat efektif dan efesien. Dilihat dari fungsi sepeda motor bagi masyarakat, mereka lebih senang pada produk sepeda motor yang dikeluarkan oleh produsen terkemuka dinegri ini, karena dirasa telah memiliki kualitas terjamin. Selama ini produk jepang mendapat tempat yang lebih tinggi dibandingkan dengan produk dari Cina maupun Korea. Berikut data penjualan sepeda motor di PT. Menara Agung Veteran.

\section{Tabel 1}

Data penjualan 5 tahun terakhir periode 2011-2015

\begin{tabular}{|c|c|c|c|c|c|}
\hline Jenis kendaraan / tahun & $\mathbf{2 0 1 1}$ & $\mathbf{2 0 1 2}$ & $\mathbf{2 0 1 3}$ & $\mathbf{2 0 1 4}$ & $\mathbf{2 0 1 5}$ \\
\hline Bebek & 2262 & 2036 & 2270 & 2000 & 2010 \\
\hline Matik & 2100 & 2210 & 2230 & 2400 & 2498 \\
\hline Sporty & 2000 & 1930 & 2110 & 2240 & 2270 \\
\hline
\end{tabular}

Berdasarkan pada latar belakang tersebut maka saya akan melakukan penelitian dengan mengambil suatu judul: "Pengaruh Bauran Pemasaran Terhadap Keputusan Pembelian Ulang Sepeda Motor Honda Di Pt. Menara Agung Veteran" (Studi kasus pada konsumen sepeda motor honda di PT. Menara Agung Veteran no.30, Padang). Jika dibandingkan dengan penelitian yang telah dilakukan fatihudin,Didin (2004) terdapat perbedaan pada variabel-variael independen yang digunakan, variabel independennya adalah tingkat pendapatan, motivasi, keluarga, kelompok referensi, atribut produk, harga juala, promosi, pelayanan dan lokasi. Sedangkan pada penelitian ini memfokuskan pada variabel-variabel bauran pemasaran yang terdiri dari produk(product), harga (price), promosi (promotion), tempat (place).

\section{LANDASAN TEORI}

Memahami, menciptakan, mengkomunikasikan, memberikan nilai dan kepuasan kepada konsumen adalah inti pemikiran dan praktek pemasaran modern. Dua sasaran pemasaran yang utama adalah menarik konsumen yang baru dengan menjanjikan nilai yang unggul dan mempertahankan konsumen yang lama. Bila pemasar dapat memahami konsumen dengan baik maka produk-produk yang mereka jual akan terjual dengan mudah.

Ada banyak defenisi yang diungkapkan oleh pakar untuk istilah pemasaran, meskipun sekilas tampak beda akan tetapi intinya sama. Perbedaan tersebut disebabkan karena para ahli memandang pemasaran ini dari sudut yang berbedabeda, diantaranya ada yang menitik beratkan pada segi fungsi, barang, kelembagaan, manajemennya dan ada juga yang memasukkan semua segi tersebut. Berikut ini pendapat beberapa para ahli mengenai defenisi pemasaran. 
Pemasaran adalah suatu sistem keseluruhan dari kegiatan-kegiatan usaha yang ditujukan untuk merencanakan, menentukan harga, mempromosikan, dan mendistribusikan barang dan jasa yang memuaskan kebutuhan kepada pembeli yang ada maupun pembelipotensial (William J.Stanton dalam Swatha dan Sukotjo, 2002 : 197).Pemasaran adalah kegiatan yang mengusahakan agar produk yang dipasar disenangi dan diterima konsumen (Gitosudarmo, 199 : 1).Pemasaran adalah suatu proses sosial yang didalamnya individu dan kelompok mendapatkan yang dibutuhkan dan ingin dengan menciptakan, menawarkan dan secara bebas mempertukarkan produk yang bernilai dengan pihak lain (Kotler, 2002 : 19).

Dari defenisi diatas maka dapat disimpulkan bahwa arti pemasaran jauh berbeda dengan penjualan. Pemasaran mencakup usaha dari pengetahuan tentang kebutuhan konsumen yang harus dipuaskan baik dari segi kualitas produk, harga, cara promosi dan penjualan produk tersebut, sehingga menjadi suatu sistem yang saling berhubungan.

Konsep pemasaran adalah filsafah manajemen pemasaran mengatakan bahawa, untuk mencapai tujuan organisasi tergantung pada penentuan kebutuhan dan keinginan pasar sasaran (target market) dan memuaskan pelanggan secara lebih efektif dan efesien dari pada dilakukan pesaing (Kotler dan Amstrong 2001 : 23). Sudah sewajarnya jika keinginan perusahaan harus dicurahkan untuk mengetahui apa yang di inginkan konsumen kemudian memuaskan konsumen tersebut dan pada akhirnya perusahaan bertujuan memperoleh laba.

Konsep pemasaran tersebut mengalami perkembangan, tetapi tidak dapat diartikan bahwa konsep pemasaran yang terakhir adalah yang terbaik. Penggunaan konsep pemasaran akan menunjang keberhasilan bisnis yang dijalankan. Berikut ada 3 unsur pokok dalam konsep pemasaran (Swatha, $2002: 18$ ).

Bauran pemasaran merupakan sebuah konsep dalam teori pemasaran modern. Bauran pemasaran adalah kombinasi dari empat variabel atau yang merupakan inti dari sistem pemasaran perusahaan, yakni: produk, harga, promosi, tempat (Swastha dan sukotjo, 2002 : 193). Secara umum bauran pemasaran menekankan pada pengertian suatu strategi yang menggabungkan antara produk (product), harga (price), promosi (promotion), tempat (place). Semua itu diarahkan untuk dapat menghasilkan omset penjualan yang maksimal atas produk yang dipasarkan pada para konsumen.

Semakin berkembangnya pengetahuan serta taraf hidup masyarakat, maka konsumen akan semakin selektif dalam memilih barang atau jasa yang akan dibelinya oleh karena itu agar dapat berhasil dalam usahanya produsen perlu memahami bagaimana konsumen memilih, membeli, memakai serta memanfaatkan barang atau jasa dalam rangka memuaskan kebutuhan atau keinginan mereka. Memahami perilaku konsumen dan mengenal pelanggan tidak pernah sederhana.

Ada beberapa pengertian dari perilaku konsumen yang diungkapkan oleh para ahli. Menurut Lamb, Hair dan McDaniel (2001 : 118) perilaku konsumen adalah proses seorang pelanggan dalam membuat keputusan membeli, juga untuk menggunakan dan membuang barang-barang dan jasa yang dibeli, juga termasuk faktor-faktor yang mempengaruhi keputusan pembelian dan penggunaan produk. 
Sedangkan menurut Women (2002 : 10) perilaku konsumen adalah studi tentang unit pembelian (buying units) dan proses pertukaran yang melibatkan perolehan, konsumsi dan pembuangan jasa, barang, pengalaman, serta ide-ide.

Berdasarkan uraian diatas, maka hipotesis yang dapat dikembangkan dalam penelitian ini adalah:

H1: Kualitas produk berpengaruh positif dan signifikan terhadap keputusan pembelian ulang sepeda motor Honda.

$\mathrm{H} 2$ : Harga berpengaruh positif dan siginifikan terhadap keputusan pembelian ulang sepeda motor Honda.

H3: Promosi berpengaruh positif dan signifikan terhadap keputusan pembelian ulang sepeda motor Honda.

H4: Tempat berpengaruh positif dan signifikan terhadap keputusan pembelian ulang sepeda motor Honda.

\section{METODOLOGI PENELITIAN}

Jenis penelitian yang dilakukan adalah kualitatif dan kuantitatif. Penelitian kuantitatif adalah penelitian yang berbentuk angka dan kualitatif yang diangkakan. Tujuan penelitian ini untuk mengetahui pengaruh produk, harga, promosi, tempat terhadap keputusan pembelian ulang sepeda motor Honda.

Sugiyono (2007:72) mendefenisikan populasi adalah wilayah generalisasi yang terdiri atas obyek atau subyek yang mempunyai kualitas dan karakteristik tertentu yang ditetapkan oleh peneliti untuk dipelajari kemudian ditarik kesimpulannya. Dalam penelitian ini populasi yang ditetapkan peneliti adalah pemilik sepeda motor Honda yang berada di veteran, Padang.

Populasi menurut Ridwan dan Akon (2006:238) adalah keseluruhan karakteristik atau inti hasil pengukuran yang menjadi objek penelitian. Sampel adalah bagian dari populasi yang mempunyai ciri-ciri atau keadaan tertentu yang akan di teliti. Populasi penelitian adalah warga yang membeli sepeda motor di pt.menara agung tahun 2015 yang berjulah 6778 .

Kuesioner merupakan teknik pengumpulan data yang dilakukan dengan cara memberi seperangkat pertanya antertulis kepada responden untuk dijawabnya (Sugiyono, 2007:135). Dalam penelitian ini responden diberi daftar pertanyaan dengan memakai alternatif jawaban yang sudah tersedia. Jawaban atas pertanyaan tersebut adalah bersifat tertutup, maksutnya alternatif jawaban atas pertanyaan tersebut telah disediakan dan responden tidak diberi kesempatan memberikan jawaban selain jawaban yang telah disediakan. Karena variabel yang diukur merupakan skala tanggapan dan tidak mempunyai standar yang sama, sehingga untuk mengukurnya digunakan teknik Likert dengan skala 1 sampai 5 yang dapat dijelaskan sebagai berikut:

- Skor 5 untuk jawaban sangat setuju

- Skor 4 untuk jawaban setuju

- Skor 3 untuk jawaban biasa

- Skor 2 untuk jawaban tidak setuju

- Skor 1 untuk jawaban sangat tidak setuju 
Variabel dependen adalah variabel terikat, yang berarti nilai dari variabel dependden tersebut dipengaruhi oleh variabel yang lain. Maka dalam penelitian ini yang bertindak sebagai variabel dependen adalah keputusan pembelian ulang.

Variabel independen merupakan variabel bebas, yang artinya nilai dari variable independen akan mempengaruhi besar kecilnya nilai dari variabel dependen. Dalam penelitian ini yang bertindak sebagai variabel independen adalah produk, harga, promosi, dan tempat.

\section{HASIL DAN PEMBAHASAN}

Tabel 2

Hasil Uji Validitas Variabel Produk

\begin{tabular}{|c|l|c|c|c|}
\hline No & \multicolumn{1}{|c|}{ Pernyataan } & $\mathbf{r}_{\text {hitung }}$ & $\mathbf{r}_{\text {tabel }}$ & Keterangan \\
\hline 1 & $\begin{array}{l}\text { Honda merupakan produk yang } \\
\text { sesuai dengan kebutuhan saya } \\
\text { untuk menunjang aktifitas sehari } \\
- \text { hari }\end{array}$ & 0.670 & 0.195 & Valid \\
\hline 2 & $\begin{array}{l}\text { Motor Honda memiliki kualitas } \\
\text { yang baik }\end{array}$ & 0.640 & 0.195 & Valid \\
\hline 3 & $\begin{array}{l}\text { Motor Honda memiliki desain } \\
\text { produk yang menarik }\end{array}$ & 0.660 & 0.195 & Valid \\
\hline 4 & $\begin{array}{l}\text { Motor Honda hemat bahan bakar } \\
\text { dan ramah lingkungan }\end{array}$ & 0.714 & 0.195 & Valid \\
\hline 5 & $\begin{array}{l}\text { Motor Honda memiliki nama } \\
\text { merek yang familiar }\end{array}$ & 0.582 & 0.195 & Valid \\
\hline
\end{tabular}

Sumber: Data diolah

Berdasarkan hasil pengolahan data, maka dapat dikemukakan bahwa hasil uji $r_{\text {hitung }}$ pada setiap item pertanyaan lebih besar daripada $r_{\text {tabel. }}$. Dengan demikian, semua item pertanyaan yang digunakan dalam kuesioner produk adalah valid.

Tabel 3

Hasil Uji Validitas Variabel Harga

\begin{tabular}{|c|l|l|l|c|}
\hline No & \multicolumn{1}{|c|}{ Pernyataan } & $\mathbf{r}_{\text {hitung }}$ & $\mathbf{r}_{\text {tabel }}$ & Keterangan \\
\hline 1 & $\begin{array}{l}\text { Motor Honda sesuai dengan } \\
\text { kualitas yang ditawarkan }\end{array}$ & 0.627 & 0.195 & Valid \\
\hline 2 & $\begin{array}{l}\text { Harga Motor Honda dapat } \\
\text { dijangkau oleh saya }\end{array}$ & 0.723 & 0.195 & Valid \\
\hline 3 & $\begin{array}{l}\text { Harga Motor Honda bersaing } \\
\text { dengan merek dan harga Motor } \\
\text { lainnya }\end{array}$ & 0.570 & 0.195 & Valid \\
\hline 4 & $\begin{array}{l}\text { Harga Motor Honda sesuai } \\
\text { dengan design yang ditawarkan }\end{array}$ & 0.733 & 0.195 & Valid \\
\hline 5 & $\begin{array}{l}\text { Harga jual Motor Honda selalu } \\
\text { bertahan di pasaran }\end{array}$ & 0.577 & 0.195 & Valid \\
\hline
\end{tabular}

Sumber: Data diolah

Berdasarkan hasil pengolahan data, maka dapat dikemukakan bahwa hasil uji $r_{\text {hitung }}$ pada setiap item pertanyaan lebih besar dari pada $r_{\text {tabel }}$. Dengan demikian, semua item pertanyaan yang digunakan dalam harga adalah valid. 
Tabel 4

Hasil Uji Validitas Variabel Promosi

\begin{tabular}{|c|l|l|l|c|}
\hline No & \multicolumn{1}{|c|}{ Pernyataan } & $\mathbf{r}_{\text {hitung }}$ & $\mathbf{r}_{\text {tabel }}$ & Keterangan \\
\hline 1 & $\begin{array}{l}\text { Pesan iklan Motor Honda di } \\
\text { televisi mudah dimengerti }\end{array}$ & 0.652 & 0.195 & Valid \\
\hline 2 & $\begin{array}{l}\text { Pesan iklan Motor Honda di } \\
\text { televise menarik untuk di tonton. }\end{array}$ & 0.628 & 0.195 & Valid \\
\hline 3 & $\begin{array}{l}\text { Desain iklan Motor Honda sesuai } \\
\text { dengan pesan iklan yang di } \\
\text { sampaikan. }\end{array}$ & 0.739 & 0.195 & Valid \\
\hline 4 & $\begin{array}{l}\text { Iklan Motor Honda di surat kabar } \\
\text { berdisain menarik }\end{array}$ & 0.772 & 0.195 & Valid \\
\hline 5 & $\begin{array}{l}\text { Pesan iklan Motor Honda di } \\
\text { televise mudah diingat. }\end{array}$ & 0.677 & 0.195 & Valid \\
\hline
\end{tabular}

Sumber: Data diolah

Berdasarkan hasil pengolahan data 4, maka dapat dikemukakan bahwa hasil uji $r_{\text {hitung }}$ pada setiap item pertanyaan lebih besar dari pada $r_{\text {tabel }}$. Dengan demikian, semua item pertanyaan yang digunakan dalam harga adalah valid.

Tabel 5

Hasil Uji Validitas Variabel Tempat

\begin{tabular}{|c|l|l|l|c|}
\hline No & \multicolumn{1}{|c|}{ Pernyataan } & $\mathbf{r}_{\text {hitung }}$ & $\mathbf{r}_{\text {tabel }}$ & Keterangan \\
\hline 1 & $\begin{array}{l}\text { Lokasi penjualan Motor Honda } \\
\text { strategis }\end{array}$ & 0.737 & 0.195 & Valid \\
\hline 2 & $\begin{array}{l}\text { Motor Honda dapat ditemukan di } \\
\text { daerah mana saja. }\end{array}$ & 0.780 & 0.195 & Valid \\
\hline 3 & $\begin{array}{l}\text { Tempat penjualan Motor Honda } \\
\text { mudah diakses }\end{array}$ & 0.638 & 0.195 & Valid \\
\hline 4 & $\begin{array}{l}\text { Produk Motor Honda terdapat } \\
\text { didaerah yang tidak strategis } \\
\text { seperti di daerah pedesaan. }\end{array}$ & 0.736 & 0.195 & Valid \\
\hline 5 & $\begin{array}{l}\text { Lokasi Motor Honda dekat } \\
\text { dengan fasilitas umum. }\end{array}$ & 0.545 & 0.195 & Valid \\
\hline
\end{tabular}

Sumber: Data diolah

Berdasarkan hasil pengolahan data 5. maka dapat dikemukakan bahwa hasil uji $r_{\text {hitung }}$ pada setiap item pertanyaan lebih besar dari pada $r_{\text {tabel }}$. Dengan demikian, semua item pertanyaan yang digunakan dalam harga adalah valid. 
Tabel 6

Hasil Uji Validitas Variabel Keputusan Pembelian Ulang

\begin{tabular}{|c|c|c|c|c|}
\hline No & Pernyataan & $\mathbf{r}_{\text {hitung }}$ & $\mathbf{r}_{\text {tabel }}$ & Keterangan \\
\hline 1 & $\begin{array}{l}\text { Saya akan membeli motor Honda } \\
\text { kembali karena produknya } \\
\text { berkualitas }\end{array}$ & 0.600 & 0.195 & Valid \\
\hline 2 & $\begin{array}{l}\text { Saya akan membeli motor Honda } \\
\text { kembali karena harganya } \\
\text { terjangkau }\end{array}$ & 0.736 & 0.195 & Valid \\
\hline 3 & $\begin{array}{l}\text { Saya akan membeli motor Honda } \\
\text { kembali karna iklannya sangat } \\
\text { menarik }\end{array}$ & 0.736 & 0.195 & Valid \\
\hline 4 & $\begin{array}{l}\text { Saya akan membeli motor Honda } \\
\text { kembali karna mutu dari } \\
\text { produknya tidak diragukan lagi. }\end{array}$ & 0.736 & 0.195 & Valid \\
\hline 5 & $\begin{array}{l}\text { Saya akan membeli motor Honda } \\
\text { kembali karena daelernya ada } \\
\text { dimana-mana. }\end{array}$ & 0.736 & 0.195 & Valid \\
\hline
\end{tabular}

Sumber: Data diolah

Berdasarkan hasil pengolahan data. maka dapat dikemukakan bahwa hasil uji $r_{\text {hitung }}$ pada setiap item pertanyaan lebih besar dari pada $r_{\text {tabel }}$. Dengan demikian, semua item pertanyaan yang digunakan dalam harga adalah valid.

Tabel 7

Hasil uji realibilitas Produk

\begin{tabular}{|c|c|c|c|c|}
\hline No & Variabel & $\mathbf{r}_{\text {hitung }}$ & $\begin{array}{c}\mathbf{r}_{\text {tabel 5\% }} \\
(\mathbf{1 0 0})\end{array}$ & Keterangan \\
\hline 1 & Produk & 0.663 & 0.195 & Reliabel \\
\hline 2 & Harga & 0.656 & 0.195 & Reliabel \\
\hline 3 & Promosi & 0.730 & 0.195 & Reliabel \\
\hline 4 & Tempat & 0.719 & 0.195 & Reliabel \\
\hline 5 & Keputusan pembelian ulang & 0.745 & 0.195 & Reliabel \\
\hline
\end{tabular}

Sumber: Data diolah

Berdasarkan perhitungkan yang dilakukan dengan menggunakan program SPSS, hasil perhitungan terhadap variabel produk sebesar 0.663 variabel harga sebesar 0.656 variabel promosi sebesar 0.730 dan variabel tempat sebesar 0,719 dan keputusan pembelian ulang sebesar 0,745. Dari hasil tersebut terlihat bahwa reliabilitas masing-masing variabel menunjukkan angka yang lebih besar dari 0,195 maka kuesioner dinyatakan reliabel. 
Tabel 8

Hasil uji normalitas

One-Sample Kolmogorov-Smirnov Test

\begin{tabular}{|c|c|c|c|c|c|c|c|}
\hline & & & Produk & Harga & Promosi & Tempat & Keputusan \\
\hline \multicolumn{3}{|l|}{ N } & 100 & 100 & 100 & 100 & 100 \\
\hline \multirow{2}{*}{\multicolumn{2}{|c|}{ Normal Parameters $^{a}$}} & Mean & 19.87 & 19.92 & 19.95 & 19.91 & 20.79 \\
\hline & & Std. Deviation & 2.097 & 2.145 & 2.556 & 2.362 & 2.571 \\
\hline \multirow[t]{3}{*}{ Most } & $\begin{array}{r}\text { Extren } \\
\text { Differenc }\end{array}$ & Absolute & .121 & .115 & .108 & .108 & .123 \\
\hline & $\mathrm{s}$ & Positive & .121 & .087 & .071 & .082 & .091 \\
\hline & & Negative & -.115 & -.115 & -.108 & -.108 & -.123 \\
\hline \multicolumn{3}{|c|}{ Kolmogorov-Smirnov Z } & 1.209 & 1.149 & 1.078 & 1.078 & 1.225 \\
\hline \multicolumn{3}{|c|}{ Asymp. Sig. (2-tailed) } & .108 & .143 & .196 & .196 & .099 \\
\hline
\end{tabular}

a. Test distribution is Normal.

Sumber: Data diolah

Uji normalitas menggunakan metode Kolmogorov-Smirnov. Cara menguji normalitas yaitu dengan membandingkan probabilitas (p) yang diperoleh dengan taraf signifikansi (a) 0,05. Apabila nilai $\mathrm{p}>$ a maka terharga normal atau sebaliknya (Singgih, 2000: 179). Hasil uji normalitas terhadap nilai residual masing-masing model persamaan dengan program SPSS 16 diperoleh nilai probabilitas di atas 0,05 hal ini menunjukkan bahwa data berharga secara normal $(p>0,05)$. Secara rinci hasil uji normalitas dapat dilihat pada tabel 9.

\section{Tabel 9}

\section{Hasil uji linearitas}

ANOVA Table

\begin{tabular}{|c|c|c|c|c|c|c|c|}
\hline & & & $\begin{array}{l}\text { Sum of } \\
\text { Squares }\end{array}$ & $d f$ & $\begin{array}{l}\text { Mean } \\
\text { Square }\end{array}$ & $\mathrm{F}$ & Sig. \\
\hline \multirow[t]{5}{*}{$\begin{array}{l}\text { y_keputusan * } \\
\text { x1_produk }\end{array}$} & $\begin{array}{l}\text { Between } \\
\text { Groups }\end{array}$ & (Combined) & 133.884 & 9 & 14.876 & & .011 \\
\hline & & Linearity & 98.690 & 1 & 98.690 & 17.058 & .000 \\
\hline & & $\begin{array}{l}\text { Deviation from } \\
\text { Linearity }\end{array}$ & 35.194 & 8 & 4.399 & .760 & .638 \\
\hline & \multicolumn{2}{|c|}{ Within Groups } & 520.706 & 90 & 5.786 & & \\
\hline & \multicolumn{2}{|l|}{ Total } & 654.590 & 99 & & & \\
\hline
\end{tabular}

Sumber: Data diolah

Berdasarkan tabel 9 tersebut dapat dilihat bahwa nilai signifikan tabel ANOVA sebesar 0.000. Artinya nilai signifikan kurang dari $0.05(0.000<0.05)$ yang berarti bahwa hubungan bersifat linier. 
Tabel 10

Hasil uji multikolonearitas

\begin{tabular}{|c|c|c|c|}
\hline Variabel & Tolerance & VIF & Kesimpulan \\
\hline Produk & 0.312 & 3.208 & Bebas multikolinearitas \\
\hline Harga & 0.278 & 3.598 & Bebas multikolinearitas \\
\hline Promosi & 0.389 & 2.569 & Bebas multikolinearitas \\
\hline Tepat & 0.296 & 3.380 & Bebas multikolinearitas \\
\hline
\end{tabular}

Sumber: data primer yang diolah

Pada uji multikolonearitas saya menggunakan rumus tolerance-VIF pada tabel diketahui bahwa nilai VIF masing-masing variabel berada disekitar angka 3 atau kurang dari 10, hal ini menunjukkan bahwa variabel independen bebas dari masalah multikolinearitas.

Tabel 11

Hasil uji heteroskedastisitas

\begin{tabular}{|c|c|c|}
\hline Variabel & Sig & Kesimpulan \\
\hline Produk & 0.267 & Tidak terjadi heteroskedastisitas \\
\hline Harga & 0.892 & Tidak terjadi heteroskedastisitas \\
\hline Promosi & 0.405 & Tidak terjadi heteroskedastisitas \\
\hline Tempat & 0.130 & Tida terjadi heteroskedastisitas \\
\hline
\end{tabular}

Sumber: data diolah

Untuk mencari hasil heteroskedastisitas saya menggunakan uji heteroskedastisitas glejser dari tabel 11 diketahui bahwa tidak terjadi heteroskedastisitas.

Tabel 12

Hasil uji regresi linear berganda

Coefficientsa

\begin{tabular}{|ll|r|r|}
\hline & & \multicolumn{2}{|c|}{ Unstandardized Coefficients } \\
\cline { 3 - 4 } Model & & \multicolumn{2}{|c|}{ Std. Error } \\
\hline 1 & (Constant) & -4.352 & 2.214 \\
& produk & .621 & .084 \\
& harga & -.502 & .124 \\
& promosi & .808 & .132 \\
& & .258 & .095 \\
\hline
\end{tabular}

a. Dependent Variable: keputusan

$$
\begin{gathered}
\mathrm{Y}=\mathrm{a}+\mathrm{bX} 1+\mathrm{bX} 2+\mathrm{bX} 3+\mathrm{bX} 4+\mathrm{e} \\
\mathrm{Y}=-4.352+0.621 \mathrm{X} 1-0,502 \mathrm{X} 2+0,808 \mathrm{X} 3+0.258 \mathrm{X} 4+\mathrm{ei}
\end{gathered}
$$

Tabel 13

Hasil uji F

\begin{tabular}{|c|c|c|c|c|}
\hline Variabel & F-hit & Sign & Alpha & Keterangan \\
\hline Produk, Harga, Promosi, Tempat & 55,051 & 0,000 & 0,05 & Signifikan \\
\hline
\end{tabular}

Sumber: data diolah

Berdasarkan ringkasan uji hipotesis $\mathrm{F}$ seperti yang dikemukakan pada tabel. Diketahui untuk variabel Produk, Harga, Promosi dan Tempat dalam keputusan pembelian ulang di PT.Menara Agung Veteran ditemukan nilai sign 
atau probability sebesar 0.000. Dalam penelitian digunakan level of significant $(\alpha)$ 5\% berarti dapat disimpulkan variabel Produk, Harga, Promosi dan Tempat terhadap konsumen di PT.Menara Agung Veteran memiliki pengaruh yang signifikan terhadap keputusan pembelian ulang sepeda motor Honda pada PT.Menara Agung Veteran secara simultan atau serempak karena nilai Sign 0.000 $<$ level of significant $(\alpha)$ sehingga Ha diterima Ho ditolak.

\section{Tabel 14}

Hasil uji t

\begin{tabular}{|c|c|c|c|c|}
\hline Variabel & T hitung & Sign & Alpha & Keterangan \\
\hline Produk & 7.356 & 0.000 & 0.05 & Signifikan \\
\hline Harga & -4.405 & 0.000 & 0.05 & Signifikan \\
\hline Promosi & 6.127 & 0.000 & 0.05 & Signifikan \\
\hline Tempat & 2.707 & 0.008 & 0.05 & Signifikan \\
\hline
\end{tabular}

Sumber: Data diolah

Berdasarkan ringkasan uji $\mathrm{t}$ seperti yang dikemukakan pada tabel. Diketahui untuk variabel Produk, Harga, Promosi dan Tempatditemukan nilai sign atau probability masing-masing sebesar 0.000. Dalam penelitian digunakan level of significant $(\alpha) 5 \%$ berarti dapat disimpulakan variabel Produk, Harga, Promosi dan Tempat secara parsial memiliki pengaruh yang signifikan terhadap keputusan pembelian ulang pada PT.Menara Agung Veteran karena nilai sigifikan masingmasing variabel bebas <level of significant $(\alpha) 5 \%$ sehingga Ha diterima dan Ho ditolak.

Tabel 15

Hasil uji koefisien determinan $\left(\mathbf{R}^{2}\right)$ Model Summary

\begin{tabular}{|l|r|r|r|r|}
\hline Model & \multicolumn{1}{|c|}{$\mathrm{R}$} & $\mathrm{R}$ Square & Adjusted R Square & Std. Error of the Estimate \\
\hline 1 & $.836^{\mathrm{a}}$ & .699 & .686 & 1.502 \\
\hline
\end{tabular}

a. Predictors: (Constant), tempat, produk, promosi, harga

Sumber: data diolah

Berdasarkan tabel 4.17mmaka ringkasan hasil korelasi dan determinasi adalah sebagai berikut:

1. $\mathrm{R}=0.836$ berarti nilai korelasi berada diantara 0.71 sampai dengan 0.90 maksutnya Produk, Harga, Promosi, dan Tempat terhadap keputusan pembelian ulang sepeda motor Honda terhadap PT.Menara Agung Veteran memiliki keeratan yang sangat kuat dan positif yang menunjukan peningkatan variabel bebas akan di ikuti oleh peningkatan variabel terikat.

2. Adjusted $R$ square $=0.669$ berarti $66.9 \%$ keputusan pembelian ulang padaPT.Menara Agung Veteran dipengaruhi olehProduk, Harga, Promosi dan Tempat Sedangkan sisanya 33.1 \%. Dipengaruhi oleh variabel lainnya selain model yang diteliti yaitu Produk, Harga, Promosi dan Tempat. Seperti gaya hidup, kebutuhan dll. 


\section{SIMPULAN}

Berdasarkan hasil analisis data dapat disimpulkan sebagai berikut:

1. Hasil uji $\mathrm{t}$ menunjukkan bahwa produk, harga, promosi dan tempat secaraparsial berpengaruh signifikan terhadap keputusan pembelian ulang. Berarti hipotesis pertama terbukti.

2. Hasil uji $\mathrm{F}$ menunjukkan bahwa produk, harga, promosi dan tempat secara bersama-sama berpengaruh positif dan signifikan terhadap keputusan pembelian ulang. Berarti hipotesis kedua terbukti.

3. Hasil perhitungan untuk nilai $\mathrm{R}^{2}$ dengan bantuan program SPSS, dalam analisis regresi berganda diperoleh angka koefisien determinasi atau $\mathrm{R}^{2}$ sebesar 0,836. Hal ini berarti $83,6 \%$ variasi perubahan keputusan pembelian ulang dijelaskan oleh variasi perubahan faktor-faktor produk, harga, promosi dan distribusi. Sementara sisanya sebesar $16,4 \%$ diterangkan oleh faktor lain yang tidak ikut terobservasi.

\section{DAFTAR PUSTAKA}

Agusty Ferdinan, 2006, Metode Penelitian Manajemen, Edisi II, Badan Penerbit Universitas Diponegoro, Semarang.

Andika, A., \& Susanti, F. (2018). Pengaruh Marketing Mix Terhadap Keputusan Pembelian Parfum di Azzwars Parfum Lubeg Padang. https://doi.org/10.31227/osf.io/upgc3

Aziz, N. (2019). Pengaruh Strategi Promosi Terhadap Keputusan Pembelian Yang Dimediasi Oleh Minat Beli Pada Konsumen Restoran KFC Cabang Khatib Sulaiman Padang. https://doi.org/10.17605/OSF.IO/V92TS

Basu Swastha dan Irawan, 2001, Manajemen Pemasaran Modern, Liberty, Yogyakarta.

Garvin,1994, Kualitas Produk: Alat Strategi Yang Penting, Free Press

David W. Cravens, 1996, Pemasaran Strategis, Edisi II, Erlangga, Jakarta.

Fandy Tjibtono, 1997, Strategi Pemasaran.Andy Offset, Yogyakarta Frank Jefkins, 1997, Periklanan, Erlangga, Jakarta.

Fernandes, Y. D., \& Marlius, D. (2018). Peranan Customer Service Dalam Meningkatkan Pelayanan Kepada Nasabah Pada PT. Bank Pembangunan Daerah Sumatera Barat Cabang Utama Padang. https://doi.org/10.31227/osf.io/wrh3p

F., \& Susanti, F. (2019). Pengaruh Faktor Psikografis Terhadap Keputusan Pembelian Sepatu Merek Mollinic Di PT. Ramayana Lestari Sentosa, Tbk Padang. https://doi.org/10.31227/osf.io/26ftz 
Fuad Mas'ud, 2004, Survai Diagnosis Organisasional, Konsep dan Aplikasi, Badan Penerbit UNDIP, Semarang.

Hair Lamb, Mc Daniel, 2001, Pemasaran, Salemba Empat, Jakarta.

Hidayati, R. R., \& Marlius, D. (2018). Aktivitas Promosi Dalam Meningkatkan Dana Pihak Ketiga Pada PT. Bank Perkreditan Rakyat (BPR) Batang Kapas Pesisir Selatan. https://doi.org/10.31227/osf.io/8dgqn

Husein Umar, 1999, Metodologi Penelitian, Aplikasi Dalam Pemasaran, Gramedia Pustaka Utama, Jakarta

Imam Ghozali, 2005, Analisis Mulitivariate dengan Program SPSS, Badan Penerbit Universitas Diponegoro, Semarang.

James Engel et al, 1994, Perilaku Konsumen, Binarupa Aksara, Jakarta.

John C Mowen dan Michael Minor, 1994, Perilaku Konsumen, Binarupa Aksara, Jakarta.

Lilik Wahyudi, 2004, Peran Harga Sebagai Indikator Kualitas dan Pengaruh Terhadap kemungkinan membeli, Fokus Manajerial, Vol.2, No.269 Nugroho.

Jamarnis, S., \& Susanti, F. (2019). Pengaruh Harga Dan Periklanan Melalui Internet Terhadap Keputusan Pembelian Produk Sabun Merek Lux Pada Mahasiswa STIE “KBP” Padang. https://doi.org/10.31227/osf.io/xz3d8

J Setiadi, 2003, Perilaku Konsumen: Konsep dan Implikasi Untuk Strategi dan Penelitian Bisnis Pemasaran, Prenada Media, Jakarta.

Marlius, D. (2017). Keputusan Pembelian Berdasarkan Faktor Psikologis Dan Bauran Pemasaran Pada PT. Intercom Mobilindo Padang. Jurnal Pundi. Volume 1. No. 1. Hal. 57-66. https://doi.org/10.31575/jp.v1i1.9

Marlius, D. (2016). Pengaruh Bauran Pemasaran Jasa Terhadap Minat Nasabah Dalam Menabung Pada Bank Nagari Cabang Muaralabuh. https://doi.org/10.31227/osf.io/vdqgx

Mayliza, R. (2019). Pengaruh Citra Perusahaan (Corporate Image) Dan Penanganan Keluhan (Complaint Handling) Terhadap Loyalitas Pelanggan (Loyality) Natasha Skin Care Di Kota Padang. https://doi.org/10.17605/OSF.IO/DF9XJ 
Nur Indriantoro dan Bambang Supomo, 1999, Metodologi Penelitian Bisnis, Edisi I, BPFE, Yogyakarta.

Philip Kotler, 2002, Manajemen Pemasaran, Edisi millenium, Jilid 2, PT. Prenhallindo, Jakarta.

Philip Kotler dan Gary Amstrong, 1997, Prinsip-Prinsip Pemasaran, Erlangga, Jakarta.

Priyanti,Y. Susanti, F. Aziz, N. (2017). Minat Beli Konsumen Toko Sepatu Bata Dipasar Raya Padang Dilihat Dari Sikap Dan Iklan. Jurnal Pundi, Vol. 01, No. 02

Sugiyono, 2004, Metode Penelitian Bisnis, Alfabeta, Bandung.

Susanti, F. (2015). Pengaruh Bauran Promosi Terhadap Keputusan Klien Dalam Memilih Radio Carano Sebagai Media Promosi Iklan. https://doi.org/10.31227/osf.io/b9ws7

Susanti, F. (2014). Pengaruh Tarif Iklan Terhadap Pendapatan Pada PT. Radio Swara Carano Batirai Indah Batusangkar. https://doi.org/10.31227/osf.io/dy863

Susanti, F. (2018). Faktor Faktor Yang Mempengaruhi Minat Beli Pada ECommerce Lazada.co.id (Studi Pada Mahasiswa Jurusan S1 Manajemen “STIE KBP” Padang). https://doi.org/10.31227/osf.io/um4yw

Susanti, F., \& Gunawan, A. C. (2019). Pengaruh Bauran Promosi Dan Harga Terhadap Keputusan Pembelian Produk Kosmetik Maybelline Di Kota Padang. https://doi.org/10.31227/osf.io/npjqh

Widayati, R. (2019). Aktivitas Pemasaran Produk Simpanan PT. Bank Tabungan Negara (Persero)Tbk Kantor Cabang Padang. https://doi.org/10.17605/OSF.IO/3Z5YC

Widayati, R. (2019). Aktivitas Pemasaran Produk Tabungan Pada PT. Bpr Rangkiang Denai Payakumbuh Barat. https://doi.org/10.17605/OSF.IO/S3UZM

William J Stanton, 1996, Prinsip Pemasaran, Jilid I, Edisi 7, Erlangga, Jakarta. 